\title{
Population dynamic of onion thrips (Thrips tabaci Lind.) occurring on leek intercropping with herbs
}

\section{Dynamika populacji wciornastka tytoniowca (Thrips tabaci Lind.) występującego na porze uprawianym współrzędnie z ziołami}

\author{
Piotr Szafranek, Dariusz Rybczyński, Bożena Nawrocka
}

\section{Summary}

The studies on reduction of flower thrips (Thrips tabaci Lind.) population occurring on leek intercropping with herbs were carried out in the Research Institute of Horticulture in 2010-2011. The following herbs were used in the experiment: savory (Satureja hortensis L.), marjoram (Origanum majorana L.) and sage (Salvia officinalis L.). The results revealed that all three species of herbs might reduce flower thrip populations in the crop. However, large variation in the effectiveness of herbs in protection leeks against thrips during the growing season was also observed.

Key words: thrips, leek, herbs

\section{Streszczenie}

Badania nad ograniczeniem występowania wciornastka tytoniowca (Thrips tabaci Lind.) w uprawie pora uprawianego współrzędnie z ziołami, przeprowadzono na polach doświadczalnych Instytutu Ogrodnictwa w Skierniewicach w latach $2010-2011$. W doświadczeniach użyto następujących ziół: cząber (Satureja hortensis L.), majeranek (Origanum majorana L.) oraz szałwia (Salvia officinalis L.). Badania wykazały, że wszystkie trzy gatunki ziół mogą wpływać na ograniczanie populacji wciornastka tytoniowca w uprawie pora. Stwierdzono także duże zróżnicowanie pod względem skuteczności ziół w ochronie pora przed wciornastkiem podczas całego sezonu wegetacyjnego.

Słowa kluczowe: wciornastki, por, zioła

\section{$\overline{\text { Instytut Ogrodnictwa }}$}

Konstytucji 3 Maja 1/3, 96-100 Skierniewice

piotr.szafranek@inhort.pl 


\section{Wstęp / Introduction}

Wciornastek tytoniowiec (Thrips tabaci Lind.) jest powszechnie występującym groźnym szkodnikiem pora (Crüger 1991; Legutowska i Klepacka 2001; Legutowska i Theunissen 2003). Jak podają Theunissen i Schelling (1997) oraz Kucharczyk i Legutowska (2003) uszkodzenia powodowane przez wciornastki mogą znacząco pogorszyć jakość roślin, w wyniku czego plon nie ma wartości handlowej.

Pomimo tego, że wciornastki jako szkodniki znane są już od bardzo dawna, ich zwalczanie wciąż sprawia wiele trudności. W dużej mierze za taki stan rzeczy odpowiada mocno ograniczony asortyment środków ochrony roślin przeznaczony do zwalczania wciornastków występujących na porze w uprawach profesjonalnych (Robak i wsp. 2011; Rogowska i wsp. 2012) oraz całkowity ich brak w uprawach ekologicznych (Śliwa 2011; Szulc 2013).

W tych drugich, w celu ochrony upraw przed organizmami szkodliwymi jakkolwiek dopuszcza się stosowanie niektórych substancji pochodzenia naturalnego, to wykorzystuje się także inne metody zwalczania szkodników. Wśród nich na szczególną uwagę zasługuje uprawa współrzędna roślin. Polega ona na wysiewaniu/wysadzaniu na polu, w swoim bezpośrednim sąsiedztwie roślin należących do dwóch lub większej liczby gatunków. Taki system uprawy nie tylko ogranicza występowanie szkodników na roślinach, ale także zmniejsza ryzyko pojawienia się na nich chorób pochodzenia bakteryjnego i grzybowego (Wiech i Kałmuk 2005). Może się on również przyczyniać do ograniczenia zachwaszczenia i zwiększenia plonu roślin.

Duże zainteresowanie naukowców, od wielu już lat, budzi możliwość zastosowania substancji pochodzenia naturalnego do walki ze szkodnikami. Szczególnie wysoki potencjał $\mathrm{w}$ tej kwestii zdają się mieć rośliny charakteryzujące się wydzielaniem dużych ilości substancji lotnych, np. zioła. Prowadzone są liczne badania mające na celu określenie przydatności różnego rodzaju wyciąów roślinnych oraz substancji lotnych uzyskiwanych z roślin do ograniczania populacji szkodników w uprawach (Koul i wsp. 2008; Nerio i wsp. 2010).

Dotychczasowe obserwacje $\mathrm{z}$ przeprowadzonych w latach 2010-2011 doświadczeń wskazuja, że majeranek, cząber i szałwia mogą wpływać na ograniczanie populacji wciornastka tytoniowca w uprawie pora.

\section{Materiały i metody / Materials and methods}

Doświadczenie przeprowadzono w latach 2010-2011, na polach doświadczalnych Instytutu Ogrodnictwa w Skierniewicach. W doświadczeniach zastosowano układ losowanych bloków, w czterech powtórzeniach, na poletkach o powierzchni $20 \mathrm{~m}^{2}$.

Zastosowano cztery kombinacje doświadczalne. Pora uprawiano współrzędnie z szałwią (Salvia officinalis L.) (1), majerankiem (Origanum majorana L.) (2) oraz cząbrem (Satureja hortensis L.) (3). W kombinacji kontrolnej (4) pora wysiano bez rośliny towarzyszącej.
W skład każdego poletka wchodziło 9 rzędów pora wysianego w rozstawie $45 \mathrm{~cm}$. W kombinacjach, w których zastosowano uprawę współrzędną, wzdłuż skrajnych rzędów poletek $\mathrm{z}$ porem posadzono rozsadę odpowiedniego gatunku ziół. Rozsadę sadzono w drugiej połowie maja w 3 rzędy przy rozstawie rzędów wynoszącej $25 \mathrm{~cm}$. W ten sposób, na każdym poletku pas składający się z 9 rzędów pora otoczony był z dwóch stron pasem 3 rzędów ziół. Odległość minimalna między ziołami, a pierwszym rzędem pora wynosiła $30 \mathrm{~cm}$.

Dla potrzeb doświadczeń zdecydowano się na siew bezpośredni nasion pora do gruntu. Nasiona zostały wysiane pod koniec kwietnia, w ilości $3 \mathrm{~kg}$ nasion na 1 ha, na głębokość około $2,0 \mathrm{~cm}$. W doświadczeniach użyto pora odmiany Jolant.

Podczas prowadzenia doświadczeń nie wykonywano zabiegów ochronnych przed chorobami roślin, stosowano natomiast ochronę przed chwastami. Lustrację roślin rozpoczęto tuż po zaobserwowaniu pierwszych roślin pora na polu. Dynamikę populacji wciornastków na porze oceniano na podstawie liczby żywych osobników wciornastków na 10 losowo wybranych roślinach z poletka.

Uzyskane wyniki poddano analizie statystycznej z wykorzystaniem programu Statistica 10 PL. Istotność różnic pomiędzy wartościami określono przy pomocy nieparametrycznego testu Kruskala-Wallisa.

\section{Wyniki i dyskusja / Results and discussion}

Wyniki uzyskane podczas doświadczeń przeprowadzonych w 2010 roku wskazują na wysoką skuteczność cząbru, majeranku i szałwii w ograniczaniu populacji wciornastka tytoniowca na roślinach pora (tab. 1). Pojawienie się wciornastków na plantacji pora obserwowano w wyżej wymienionym roku stosunkowo późno na początku lipca. Ponadto, aż do momentu zbiorów populacja szkodników utrzymywała się w badanych obiektach na stosunkowo niskim poziomie (tab. 1). Różnice w liczebności szkodnika na roślinach znajdujących się w kombinacji kontrolnej i w pozostałych kombinacjach, w których zastosowano uprawę współrzędną obserwowano przez cały okres wegetacyjny. Jedynie w lipcu, nie stwierdzono różnic statystycznych w liczebności szkodnika znajdującego się na porze uprawianym $\mathrm{z}$ cząbrem $\mathrm{W}$ stosunku do kombinacji kontrolnej. Przez cały okres badań nie zaobserwowano także różnic pomiędzy trzema badanymi gatunkami ziół w skuteczności ograniczania populacji wciornastków. W zależności od okresu, liczebność szkodnika na porze uprawianym z ziołami była najczęściej dwu- lub trzykrotnie niższa niż na roślinach kontrolnych.

Powtórzenie badań w 2011 roku dało bardziej zróżnicowane wyniki. Inaczej przedstawiała się także zmiana liczebności wciornastków $\mathrm{w}$ trakcie sezonu. Szkodnik pojawił się na roślinach pora już w czerwcu i pomimo, że przez pierwsze trzy miesiące jego liczebność regularnie rosła, to przez cały ten okres pozostawała jednak na stosunkowo niskim poziomie. Sytuacja zmieniła się natomiast wyraźnie we wrześniu, kiedy nastąpił gwałtowny wzrost liczebności szkodnika osiagając w paździer- 
niku wartość nawet ponad 35 osobników na roślinę (tab. 2). Dla porównania, podczas badań prowadzonych w 2010 roku zaobserwowano maksymalnie 7,2 wciornastka na roślinę (tab. 1). W czerwcu 2011 roku nie odnotowano różnic w liczebności agrofagów w poszzególnych kombinacjach. Podczas obserwacji prowadzonych natomiast w kolejnych dwóch miesiącach, zaobserwowano różnice pomiędzy badanymi kombinacjami. Zarówno w lipcu, jak i w sierpniu wciornastki najliczniej występowały na porze w kombinacji kontrolnej. W tym okresie czasu jedynie w przypadku pora uprawianego z cząbrem w lipcu nie stwierdzono różnic $\mathrm{w}$ stosunku do kombinacji kontrolnej. We wrześniu, kiedy to nastąpiło zdecydowane zwiększenie liczby szkodników na porze, najmniej stwierdzono ich na kombinacji, w której pora uprawiano $\mathrm{z}$ cząbrem. Pod koniec sezonu liczba wciornastków na porze $\mathrm{w}$ kombinacji kontrolnej była większa niż w pozostałych kombinacjach (tab. 2).

Możliwości zastosowania olejków eterycznych z różnych roślin do odstraszania i zwalczania szkodników są od wielu lat przedmiotem badań na całym świecie (Koul i wsp. 2008; Nerio i wsp. 2010). Wpływ olejków eterycznych uzyskanych z ziół na zachowanie wciornastka tytoniowca badali Koschier i Sedy (2003). Autorzy wykazali, że olejek uzyskany z rozmarynu (Rosmarinus officinalis L.) działa na wciornastki repelentnie w stężeniu $10 \%$. Zastosowanie natomiast olejków $\mathrm{z}$ majeranku (O. majorana) i mięty (Mentha arvensis L.) już w $0,1 \%$ stężeniu spowodowało istotne zahamowanie składania jaj przez owady w stosunku do kombinacji kontrolnej, w której liść pora nie został potraktowany olejkiem. Olejki z lawendy (Lavandula angustifolia L.) i szałwii (S. officinalis) bardzo wyraźnie wpływały na ten proces w stężeniach odpowiednio 1 i $0,1 \%$. Koschier i wsp. (2002) udowodnili także, że zastosowanie na liściach pora olejków z majeranku, rozmarynu, mięty i lawendy powoduje ograniczenie żerowania wciornastków na roślinach. Nie zaobserwowali natomiast żadnego wpływu badanych substancji na śmiertelność owadów. W doświadczeniach prezentowanych $\mathrm{w}$ niniejszej pracy do odstraszania wciornastków z uprawy, zamiast olejków, zastosowano uprawę współrzędną aromatycznych ziół $\mathrm{z}$ porem. Zamiarem takiego działania było wstępne sprawdzenie, czy rosnące w polu zioła będą równie skuteczne w odstraszaniu wciornastków, jak olejki pozyskiwane z nich na drodze destylacji. Podczas prowadzenia doświadczeń, podobnie, jak w badaniach Koschier i wsp. (2002) stwierdzono działanie repelentne majeranku w stosunku do wciornastka tytoniowca. Działanie takie stwierdzono również w przypadku szałwii chociaż Koschier i Sedy (2003) stosując na szkodniki olejek szałwiowy takiego działania nie zaobserwowali. Olejek z cząbru do tej pory nie był obiektem badań pod kątem stosowania go jako środka o działaniu odstraszającym T. tabaci. Repelentne właściwości olejku z majeranku (O. majorana) w stosunku do wciornastka tytoniowca stwierdzili także van Tol i wsp. (2007). Redukcja liczebności wciornastków na tablicach lepowych potraktowanych tym olejkiem wynosiła $87 \%$ w stosunku do kombinacji kontrolnej. Nieco mniejszą skuteczność stwierdzono natomiast $\mathrm{w}$ przypadku zastosowania $\mathrm{w}$ doświadczeniach olejku z bazylii (Ocimum gratissimum L.) $71 \%$ (van Tol i wsp. 2007).

Tabela 1. Średnia liczba wciornastków na 1 roślinie

Table 1. Average number of thrips per one plant

Doświadczenie polowe, Skierniewice 2010 - Field experiment, Skierniewice 2010

\begin{tabular}{l|c|c|c|c|c}
\hline \multirow{2}{*}{$\begin{array}{c}\text { Kombinacja } \\
\text { Combination }\end{array}$} & \multicolumn{5}{|c}{ Data obserwacji - Date of observation } \\
\cline { 2 - 6 } & $\begin{array}{c}\text { czerwiec } \\
\text { June }\end{array}$ & $\begin{array}{c}\text { lipiec } \\
\text { July }\end{array}$ & $\begin{array}{c}\text { sierpień } \\
\text { August }\end{array}$ & $\begin{array}{c}\text { wrzesień } \\
\text { September }\end{array}$ & $\begin{array}{c}\text { październik } \\
\text { October }\end{array}$ \\
\hline Cząber - S. hortensis & 0,0 & $2,6 \mathrm{ab}$ & $2,5 \mathrm{~b}$ & $2,9 \mathrm{~b}$ & $2,2 \mathrm{~b}$ \\
\hline Majeranek - O. majorana & 0,0 & $1,6 \mathrm{~b}$ & $2,1 \mathrm{~b}$ & $3,0 \mathrm{~b}$ & $3,1 \mathrm{~b}$ \\
\hline Szałwia - S. officinalis & 0,0 & $1,5 \mathrm{~b}$ & $1,9 \mathrm{~b}$ & $1,8 \mathrm{~b}$ & $2,4 \mathrm{~b}$ \\
\hline Kontrola - Control & 0,0 & $5,6 \mathrm{a}$ & $6,2 \mathrm{a}$ & $2,2 \mathrm{a}$ & $5,6 \mathrm{a}$ \\
\hline
\end{tabular}

Test Kruskal-Wallis; średnie oznaczone tą samą literą nie różnią się istotnie przy $\alpha=0,05$

Kruskal-Wallis test; average values marked with the same letter are not statistically different at $\alpha=0.05$

Tabela 2. Średnia liczba wciornastków na 1 roślinie

Table 2. Average number of thrips per one plant

Doświadczenie polowe, Skierniewice 2011 - Field experiment, Skierniewice 2011

\begin{tabular}{l|c|c|c|c|c}
\hline \multirow{2}{*}{$\begin{array}{c}\text { Kombinacja } \\
\text { Combination }\end{array}$} & \multicolumn{5}{c}{ Data obserwacji - Date of observation } \\
\cline { 2 - 6 } & $\begin{array}{c}\text { czerwiec } \\
\text { June }\end{array}$ & $\begin{array}{c}\text { lipiec } \\
\text { July }\end{array}$ & $\begin{array}{c}\text { sierpień } \\
\text { August }\end{array}$ & $\begin{array}{c}\text { wrzesień } \\
\text { September }\end{array}$ & $\begin{array}{c}\text { październik } \\
\text { October }\end{array}$ \\
\hline Cząber - S. hortensis & $1,3 \mathrm{a}$ & $2,2 \mathrm{ac}$ & $2,3 \mathrm{~b}$ & $13,4 \mathrm{~b}$ & $23,3 \mathrm{~b}$ \\
\hline Majeranek - O. majorana & $1,0 \mathrm{a}$ & $1,3 \mathrm{~b}$ & $2,7 \mathrm{~b}$ & $19,7 \mathrm{a}$ & $25,5 \mathrm{~b}$ \\
\hline Szałwia - S. officinalis & $0,7 \mathrm{a}$ & $1,7 \mathrm{bc}$ & $2,5 \mathrm{~b}$ & $20,0 \mathrm{a}$ & $25,5 \mathrm{~b}$ \\
\hline Kontrola - Control & $1,5 \mathrm{a}$ & $3,5 \mathrm{a}$ & $5,5 \mathrm{a}$ & $24,2 \mathrm{a}$ & $35,2 \mathrm{a}$ \\
\hline
\end{tabular}

Test Kruskal-Wallis; średnie oznaczone tą samą literą nie różnią się istotnie przy $\alpha=0,05$

Kruskal-Wallis test; average values marked with the same letter are not statistically different at $\alpha=0.05$ 
Uzyskane podczas prowadzenia doświadczeń wyniki wskazują, że stosowanie uprawy współrzędnej pora z ziołami $\mathrm{w}$ celu ochrony plantacji przed wciornastkiem tytoniowcem jest zasadne. Należy jednak zwrócić uwagę na zróżnicowaną podczas trwania sezonu skuteczność ziół jako repelentów działających w warunkach naturalnych. Dzięki swoim właściwościom zioła powinny znaleźć zastosowanie przede wszystkim w uprawach ekologicznych, w których zwalczanie szkodników ze względu na liczne ograniczenia jest trudne.

\section{Wnioski / Conclusions}

1. Majeranek, szałwia i cząber w uprawie współrzędnej z porem moga wpływać na ograniczanie występowania na nim wciornastka tytoniowca.
2. Skuteczność majeranku, szałwii i cząbru uprawianych współrzędnie z porem w ograniczaniu występowania na nim wciornastka tytoniowca w ciagu sezonu wegetacyjnego jest zróżnicowana.

Praca została wykonana w ramach Programu Wieloletniego „Rozwój zrównoważonych metod produkcji ogrodniczej w celu zapewnienia wysokiej jakości biologicznej i odżywczej produktów ogrodniczych oraz zachowania bioróżnorodności środowiska i ochrony jego zasobów" finansowanego przez Ministerstwo Rolnictwa i Rozwoju Wsi.

\section{Literatura / References}

Crüger G. 1991. Zwiebelgemüse. p. 130-145 In: "PflanzenschutzimGemüsebau” (G. Crüger, ed.). Eugen Ulmer GmbH Co, Stuttgard, $344 \mathrm{pp}$.

Koschier E.K., Sedy K.A. 2003. Labiate essential oils affecting host selection and acceptance of Thrips tabaci lindeman. Crop Prot. 22: 929-934.

Koschier E.K., Sedy K.A., Novak J. 2002. Influence of plant volatiles on feeding damage caused by the onion thrips Thrips tabaci. Crop Prot. 21: 419-425.

Koul O., Walia S., Dhaliwal G.S. 2008. Essential oils as green pesticides: potential and constraints. Biopestic. Int. 4 (1): $63-84$.

Kucharczyk H., Legutowska H. 2003. Thrips tabaci as a pest of leek cultivated in different conditions. p. 211-213. In: Thrips and Tospoviruses. Proc. 7th International Symposium on Thysanoptera. Italy, July, 2-7, 2001, 386 pp.

Legutowska H., Klepacka K. 2001. Współrzędna uprawa pora z różnymi gatunkami roślin a występowanie szkodliwej fauny. [Leek intercropped with different plant varieties and occurrence of injurious fauna]. Prog.Plant Prot./Post. Ochr. Roślin 41 (2): $544-547$.

Legutowska H., Theunissen J. 2003. Thrips species in leeks and their undersown intercrops. Integrated control in field vegetable crops. IOBC/WPRS Bull. 26 (3): 177-182.

Nerio L.S., Olivero-Verbel J., Stashenko E. 2010. Repellent activity of essential oils: A review. Bioresource Technol. 101 (1): $372-378$.

Robak J., Sobolewski J., Ostrowska A., Rogowska M., Wrzodak R., Anyszka Z. 2011. Program ochrony warzyw uprawianych w polu przed chorobami i szkodnikami. s. 7-186. W: „Program ochrony roślin warzywnych 2011” (E. Wiącek, red.). Hortpress Sp. z o.o., Warszawa, 248 ss.

Rogowska M., Szwejda J., Wrzodak R. 2012. Szkodniki. s. 103-198. W: „Program ochrony roślin warzywnych 2012” (A. Czarnocka, red.). Hortpress Sp. z o.o., Warszawa, 268 ss.

Szulc M. 2013. Wykaz środków ochrony roślin zakwalifikowanych do stosowania w rolnictwie ekologicznym. www.ior.poznan.pl/19, wykaz-sor-w-rolnictwie-ekologicznym.html?wiecej=26, dostęp: 15.04.2013.

Śliwa B. 2011. Wykaz środków ochrony roślin zakwalifikowanych do stosowania w rolnictwie ekologicznym. www.ior.poznan.p1/19, wykaz-sor-w-rolnictwie-ekologicznym.html?wiecej=26, dostęp: 08.11.2012.

Theunissen J., Schelling G. 1997. Damage threshold for Thripstabaci (Thysanoptera: Thripidae) in monocropped and intercropped leek. Eur. J. Entomol. 94: 253-261.

Wiech K., Kałmuk J. 2005. Uprawy współrzędne sposobem na urozmaicenie agrocenoz i zmniejszenie użycia pestycydów. s. 126-136. W: „Ochrona środowiska naturalnego w XXI wieku - nowe wyzwania i zagrożenia” (K. Wiech, H. Kołoczek, P. Kaszycki, red.). TEXT, Kraków, 136 ss

van Tol R.W.H.M., James D.E., De Kogel W.J., Teulon D.A.J. 2007. Plant odours with potential for a push-pull strategy to control the onion thrips, Thripstabaci. Entomol. Exp. Appl. 122 (1): 69-76. 